\title{
A 'Primus Inter Pares' in EU Foreign Policy? - German Leadership in the European Council during the Libyan and Ukrainian Crises
}

\author{
INEZ VON WEITERSHAUSEN, DAVID SCHÄFER* and \\ WOLFGANG WESSELS
}

\begin{abstract}
Drawing on the characterisation of the European Council as an arena for 'integrative bargaining', the paper shows the importance of two factors that influence whether a country can act as 'first among equals' or ('Primus Inter Pares') in a system designed to respect national sovereignty: alignment among the 'Big Three', and 'voice opportunities' for smaller member states. We support this argument with view of Germany's divergent role in two recent international crises - the 2011 uprisings in Libya and the violent protests in Ukraine in 2014/2015. On the basis of these findings, we conclude that the ability to create consent among all Member States is both a key prerequisite and a serious challenge for effective leadership in EU foreign policy.
\end{abstract}

The European Council is the 'centre of political gravity' and the 'key institution' for formulating and coordinating foreign-policy in the Europe Union (EU) (Puetter 2013; Wessels 2016). Characterised by intergovernmental decision-making procedures, it produces conclusions, decisions and regulations which represent the shared positions of the elected heads of states or government of all Member States. Accordingly, any one country's potential for leadership is limited to it being Primus Inter Pares or 'first among equals', which, in turn, depends on its ability to 'mobilis(e) others to want to struggle for shared aspirations' (Kouzes and Posner 1991, 30).

In the following, we elaborate on this notion by first identifying the conditions that enable states to become Primus inter Pares and by then applying them to the case of Germany and its potential for leadership in the area of crisis response. We suggest that the alignment of interests or preferences among the Big Three (see e.g. Krotz and Maher 2016) on the one hand, and the extent to which smaller member states are given the ability to exercise 'voice opportunities' (Grieco 1995) on the other hand, are crucial in determining a country's potential to exercise this unique position of leadership. With view of Berlin's interaction with its European partners during the 2011 uprisings in Libya and the 2014 violent protests in Ukraine, we furthermore show how

\footnotetext{
*The information and views set out in this article are those of the author and do not necessarily reflect the official opinion of the European Commission.
} 
domestic public opinion influences whether and how leadership is exercised. Analyzing Member States' interactions before, during and shortly after European Council summits and reviewing documents such as Council conclusions, decisions and EU regulations, we arrive at rather different outcomes: In Libya Germany's relative importance, and in particular its ability to pursue foreign policy through its preferred instruments of constructive dialogue and non-military coercive measures such as economic sanctions, diminished quickly after the government of Angela Merkel abstained on the vote on UN Security Council resolution 1973, and subsequently refused to take part in the military intervention against the Gaddafi Regime. As decision-making increasingly shifted from the European Council to NATO, Germany therefore lost its ability to exercise a leadership role during the crisis. Meanwhile, smaller member states were deprived of an important forum to effectively make their voices heard as the European Council lost in relative importance.

By contrast, during the events in Ukraine in 2014/15, Germany, France and the UK agreed that constructive engagement, economic sanctions and other coercive measures were preferable over military action. By regularly consulting smaller member states, Berlin established itself as a key advocate of their security concerns in the European Council which served as an effective forum for interaction. Also with view of the intense debate among domestic stakeholders in Germany regarding the 'right' way of engaging with Moscow, the European Council proved to be relevant as a joint European approach also strengthened the legitimacy of the German government's positon. ${ }^{1}$

\section{LEADERSHIP IN EU FOREIGN POLICY}

Unlike the European Commission, whose influence originates from the expertise of its staff and its financial discretion, the European Council is not a powerful actor in its own right. Rather, it derives its meaning from acting as a forum for interaction and negotiation which facilitates cooperation among its 28 member states and thereby has, for a long time, promoted European integration (Puetter 2014; Fabbrini 2013, 2014; Bickerton, Hodson, and Puetter 2015). While the European Council has frequently been criticised for its tendency to produce outcomes based on the smallest common denominator (Wagner 2011), it has played a crucial role in formulating EU foreign policy since the beginnings of European Political Cooperation (EPC) ${ }^{2}$. More recently, the creation of a permanent presidency, which can act as moderator and consensus broker among member states, and the nomination of a High Representative of the EU for Foreign Affairs and Security Policy (HR/VP) have further promoted the European Council's ability to provide 'strategic leadership' and 'guidance' (Keukeleire and MacNaughtan 2008, 68; Vanhoonacker 2011, 88) in, the EU's external relations. In addition, Member States have increasingly sought to strengthen the European Council's profile as a crisis manager and to improve its capacity to 'identify strategic interests and objectives' (Art. 22(1) TEU).

While the heads of state or government have adopted declarations on major critical events and developments in the international system in no less than 90 per cent of summit conclusions (Kranz 2011), Member States' ability and willingness to cooperate has remained a challenge, however. A key obstacle in this regard has been the unanimity requirement, which still prevails in most foreign policy matters. It refers to the fact that 
in the EU it is not sufficient that the largest and most powerful countries, whose resources and expertise are essential for foreign policy action to take place in the first place, agree on a given matter (Wessels 2016, 223). Rather, also the approval and support of smaller member states is needed, i.e. they must be given opportunities to 'voice their concerns and interests' to 'prevent or at least ameliorate their domination' by a stronger party (Grieco 1995, 34). ${ }^{3}$

Closely related to this finding is the conceptualisation of the European Council as an 'integrative system of balancing' ${ }^{4}$ (Link 1997, 15). The term builds on the insight that, while smaller member states may lack the resources to pursue an active foreign policy on their own, they often have a set of concentrated interests and expertise in a particular area which enable them to contribute to the decision-making process with valuable insights into a specific topic. In the realm of foreign policy, they may, for instance, have special knowledge or ties to a country or region that can provide important expertise to the EU overall or in a specific scenario. As a consequence, all member states can exercise some degree of influence, and even leadership, as long as they are aware of and know how to make use of the formal and informal mechanism that at their disposal. In concrete terms, this may find expression in member states' calling for (extraordinary) summits, in their engagement with the (standing) President of the European Council (Tömmel 2017), or in efforts to lobby other member states ahead of the actual summits.

These insights about the role of smaller member states notwithstanding, it is usually for the 'Big Three', i.e. France, Germany and - prior to Brexit - the UK to determine the EU's course of action on major foreign policy decisions. Due to their extensive resources, they are able to advocate specific courses of action and pursue their interests more actively and successfully than others on a European stage, thus acting as Primus Inter Pares or 'first among equals'. The term acknowledges the fact that even though formal power resources (e.g. number of votes) are equally distributed among Member States informal power resources, such as superior diplomatic and intelligence services, economic strength, and military capabilities, enable states to bring about specific outcomes (Kouzes and Posner 1991, 30). Whether the result is then perceived as a form of 'hegemony', i.e. the ability to 'dominate all other states in the system' (Mearsheimer 2003, 40) and to unilaterally 'maintain the essential rules governing interstate relations' (Keohane and Nye 1977, 44 ), or as (benevolent) 'leadership' (Lentner 2005, 736-738) depends on the 'follower states' (Clark 2011, 19). Domestic interests and public opinion. Moreoever, it it has been shown that ideational consensus, common interests, and shared norms can serve as coalition magnets (Béland and Cox 2016) and reduce volatility in decision-making, partnerships and alliances. Therefore, the following section identifies core interests and ideas which have shaped Germany's foreign policy since the second half of the 20th century. Ultimately, they form the basis for its potential to act as Primus Inter Pares.

\section{GERMAN FOREIGN POLICY: BETWEEN CONTINUITY AND CHANGE}

While foreign policy is by nature highly idiosyncratic, context-bound and the result of an interplay of interests, resources and capabilities on the one hand and past 
experiences, traditions and narratives on the other hand, German foreign policy is peculiar. It differs significantly from those of other powerful states, including its close European allies, France and Great Britain, and has frequently been referred to as 'civilian' in nature (Maull 2000). This has usually been ascribed to the legacy of the Third Reich, the unconditional surrender in 1945, and the subsequent division into two states. In particular, (West-) Germany is thus seen as having developed its post-World War II identity in close association with the project of European integration (Paterson 2011; Siddi 2016, 41-43). As the country's policies have traditionally been directed towards establishing Germany as a reliable partner, firmly embedded in the security and foreign policy institutions of the Western allies (Bulmer and Paterson 2010; Oppermann 2012, 504-506), its decision-makers and population tended to be deeply sceptical towards military engagement and expressed a strong preference for diplomatic and political tools. In a poll from 2013, 65 per cent of Germans still indicated a preference against deploying additional military forces abroad, and more than one third wanted an end to any German foreign military engagement (YouGov 2013).

In line with these observations, German decision-makers have preferred to 'lead from behind' (Paterson 2011, 57) and portrayed an unequivocal commitment to multilateralism and a firmly integrationist policy with regard to the EU (Katzenstein 1997). While the EU became indeed an ideal institutional venue for Germany to act within (Allers 2016, 521), Berlin often left the initiative for specific actions and contentious policies, including in the realms of security and defense, to other member states (Katzenstein 1997, 25; Gross 2007; Paterson 2011, 57; Olender 2012,3). According to policy-makers and diplomats at the time, German governments were, for instance, most ready to follow the lead of their French counterparts in responding to situations like the Russian invasion of Afghanistan, the Venice declaration on the two-state doctrine in the Middle East, or the atrocities in the civil wars in the Balkans. Over time, however, Germany's foreign policy has arguably become more assertive. Beginning with the chancellorship of Gerhard Schröder (1998-2005), the notion of 'reflexive multilateralism' (Smith 1996) was increasingly replaced by that of a 'normalisation' (Bulmer and Paterson 2010; Oppermann 2012, 504-506) and a more strategic pursuit of interests (Kundnani 2012). Often ascribed to a new sense of self-confidence and a growing desire to assume a new and more powerful role in and outside Europe, this change was also reflected in the way in which Berlin interacted with its partners in the European Council.

Despite continuing to seek close cooperation with established and powerful partners and simultaneously building on the expertise and involvement of smaller member states, Germany's new profile as a 'normalized country' (Bulmer and Paterson 2010) has made it more vulnerable to criticism, however. Raising the question whether Berlin had departed from its 'European vocation' (Krotz and Schild 2016; see also Katzenstein 1997, 26) and its past role as Europe's 'tamed power' (Katzenstein 1997), the academic debate has increasingly revolved around the status quo and future direction of German foreign policy. To provide further insights into this regard, we will now analyse how Berlin has interacted with its partners in the European Council during two recent foreign policy crises. 
GERMAN LEADERSHIP IN THE EUROPEAN COUNCIL? - INSIGHTS FROM TWO CRISES IN THE EU'S NEIGHBOURHOOD

In 2015, the EU's foreign policy discourse was characterised by the idea that 'crisis had become the new normal' (Witney and Dennison 2015). After a series of upheavals and violence in numerous countries in the Middle East and North Africa, commonly referred to the 'Arab Spring', first struck Europe's Southern neighbourhood, 'Russian pressure on Ukraine, Georgia, Moldova and Armenia (...) impacted (...) the EU's ability to deliver on its regional objectives' (Koehler 2014, 2) to the East. The perception of being surrounded by a 'ring of fire' (Koehler 2014, 2) rather than a group of friends, led to a multitude of policy proposals, initiatives and mechanisms ${ }^{5}$ at the EU-level that reflected the Union's joint commitment to 'develop a special relationship with neighbouring countries, aiming to establish an area of prosperity and good neighbourliness, founded on the values of the Union' (Art. 8 Treaty of Lisbon). As many member states were keen to also develop individual answers however questions regarding internal coherence and effective leadership soon arose. Focusing on Germany's role in the European Council during the Libyan crisis in 2011 and the situation in Ukraine in 2014/15, the subsequent sections will elaborate on these aspects in more detail.

\section{A POTENTIAL LEADER, SIDE-LINED: GERMANY IN LIBYA}

On 17 February 2011, Libyan citizens took to the streets of Tripoli and other major cities to protest against the government of long-term leader Colonel Muammar al-Gaddafi. While uprisings of a similar kind had previously occurred in neighbouring Tunisia and Egypt (Delacoura 2012), in Libya they soon escalated into a civil war with significant engagement by foreign powers (see Koenig in this special issue, von Weitershausen 2015). While the effects of increasing insecurity and instability were felt most strongly in Libya itself, also European states were affected by the events. In response, Member States first terminated the EU-Libya cooperation agreement on political, economic, social and cultural dialogue, and on 28 February 2011 agreed on restrictive measures to reinforce UN Security Council Resolution 1970. The latter condemned the use of force against civilians, the repression and violations of human rights, and attempts by the Libyan government to incite violence, and subjected numerous individuals to travel bans and assets freezes and triggered Council Decision 2011/137/CFSP which introduced a weapons embargo, a no-fly zone over Libyan airspace, restrictions on admitting certain persons into European Union (EU) territory and the freezing of their economic resources. In March 2011, Council Regulation (EU) 204/2011 prohibited to 'sell, supply, transfer, export, purchase, import or transport from Libya equipment which might be used for internal repression' and Council Decision 2011/178/ CFSP banned flights of Libyan aircraft in EU airspace and vice versa, and introduced exceptions to the asset freezes (Table 1).

Despite these joint early initiatives, however, Germany soon lost its influence when diverging and competing interests led to unilateral and bilateral initiatives. After Italy's and Malta's initial opposition to take a hard stance against the Gaddafi regime Paris' failed to convince its partners to recognise the National Transitional Council (NTC) 
TABLE 1

TIMELINE LIBYA - KEY DECISIONS AND ACTIONS (FEBRUARY-APRIL 2011)

\begin{tabular}{|c|c|c|}
\hline Date & Measure & Level of activity \\
\hline 19/02/2011 & UK and France revoke licenses for the export of arms to Libya & National \\
\hline $22 / 02 / 2011$ & $\begin{array}{l}\text { Suspension of EU-Libya cooperation agreement on political, economic, } \\
\text { social and cultural dialogue and cooperation on migration }\end{array}$ & Commission \\
\hline 24-25/02/2011 & Consultations among EU Energy minister on the situation in Libya & Council \\
\hline $26 / 02 / 2011$ & $\begin{array}{l}\text { SC Resolution 1970 } \\
\text { - authorises all (UN) member states to seise and dispose of military-related } \\
\text { materiel banned by the text } \\
\text { - calls on all (UN) member states to facilitate and support the return of } \\
\text { humanitarian agencies and make available humanitarian and related } \\
\text { assistance in Libya } \\
\text { - expresses readiness to consider taking additional appropriate measures as } \\
\text { necessary } \\
\text { - establishes a committee to monitor sanctions, to liaison with member } \\
\text { states on compliance, to respond to violations and to designate the } \\
\text { individuals subject to the targeted measures } \\
\text { - lists all individuals and entities immediately subjected to the targeted } \\
\text { sanctions in an Annex to the resolution }\end{array}$ & UN SC \\
\hline 28/02/2011 & $\begin{array}{l}\text { Council Decision 2011/137/CFSP } \\
\text { - adopts measures 'to reinforce the UN Security Council-mandated } \\
\text { sanctions' (see above) } \\
\text { - provides for the freezing of their economic resources }\end{array}$ & $\begin{array}{l}\text { European } \\
\text { Council }\end{array}$ \\
\hline $02 / 03 / 2011$ & $\begin{array}{l}\text { Council Regulation (EU) } \mathbf{2 0 4 / 2 0 1 1} \\
\text { - implements a legal prohibition to sell, supply, transfer, export, purchase, } \\
\text { import or transport from Libya equipment which might be used for } \\
\text { internal repression } \\
\text { - provides technical assistance or brokering services related to equipment } \\
\text { which might be used for internal repression } \\
\text { - freezes funds and economic resources of listed persons, entities and } \\
\text { bodies }\end{array}$ & $\begin{array}{c}\text { European } \\
\text { Council }\end{array}$ \\
\hline 23/03/2011 & $\begin{array}{l}\text { Council Decision 2011/178/CFSP } \\
\text { amends Decision 2011/137/CFSP } \\
\text { - bans flights of Libyan aircraft in EU airspace and vice versa } \\
\text { - introduces exception to asset freezes }\end{array}$ & $\begin{array}{l}\text { European } \\
\text { Council }\end{array}$ \\
\hline $01 / 04 / 2011$ & $\begin{array}{l}\text { Council Decision 2011/210/CFSP } \\
\text { - expresses the 'Union's readiness to provide Common Security and } \\
\text { Defence Policy support to humanitarian assistance in response to a } \\
\text { request from the United Nations Office for the Coordination of } \\
\text { Humanitarian Affairs (OCHA) and under the coordination role of the } \\
\text { - United Nations' } \\
\text { - thereby sets the preconditions for EUFOR Libya }\end{array}$ & $\begin{array}{l}\text { European } \\
\text { Council }\end{array}$ \\
\hline
\end{tabular}

during the EU summit on 11 March 2011, These disagreements set the tone for events in the following months during which France chose to unilaterally engage with the NTC members, before becoming, together with the UK, the key promoter of military action (Adler-Nissen and Pouliot 2014). ${ }^{6}$ Using their long-term experience as permanent members of the UN Security Council, the French and British delegations took 'control of the pace of the diplomatic process', 'twisted UN procedures to their advantage' and imposed their own 'evidence and frames even in the face of contrary reports of other member states' embassies in Tripoli'.

While London and Paris hence demonstrated their limited interest in and concern for the objections of several of its European partners, Germany's abstention on the UN vote 
reflected wider concerns about policies leading to regime change. Indeed, it was only a minority of member states, namely Belgium, Bulgaria, Denmark, Greece, France, Italy, the Netherlands, Sweden, Spain, Romania, and the United Kingdom, which eventually participated in the NATO Operation Unified Protector. In the context of the latter, decision-making increasingly moved to the North Atlantic Council (NAC), where the US and other influential countries played a more important role (Koenig 2012; Del Sarto 2016, 225) and the European Council lost its ability to function as a place for integrative bargaining and smaller states lost an important voice opportunity. They, therefore, remained either relatively uninvolved or changed their policies and take a more proactive approach. The latter strategy was pursued, for instance, by Italy and Malta, whose close business and political relationships to Libya under Gaddafi had initially made them sceptical of taking hard measures, but which soon became key actors. ${ }^{7}$ In light of these developments, it is hardly surprising that one observer suggested that 'the CFSP died in Libya - we just have to pick a sand dune under which we can bury it' (Armellini 2011). ${ }^{8}$

Given that Germany's abstention from the UN vote was met with significant criticism domestically (Miskimmon 2012; Oppermann and Spencer 2018) and by Western partners - an article in the Washington Post argued that a 'fundamental shift in interests and outlook' threatened the 'entire Western alliance' (Bremmer and Leonard 2012) - one may wonder what triggered this contentious decision in the first place. Most accounts have focused on personal preferences of the relevant leaders, or strategic considerations in the face of upcoming elections (Oppermann 2012, 514515, Bucher et al. 2013). ${ }^{9}$ A less prominent explanation proposes that Germany's isolation was in fact unintentional. This interpretation sees unawareness of the change of attitude in the Obama administration, which had initially been reluctant to intervene militarily in yet another Middle Eastern country at the core of the developments in March 2011 (Brockmeier 2013). With regard to the relevance of interest alignment among the Big Three this point is particularly relevant as it implies a lack of interaction and coordination between France, the UK and Germany, and demonstrates the implications this has on German leadership.

We conclude that, despite being backed by the majority of the population, the German government's action during the Libyan crisis demonstrated the limits of Berlin's leadership when preferences among the larger member states diverge, and the European Council is weakened. It also illustrated the detrimental effects this can have for smaller member states.

Following the Libyan crisis, several developments significantly altered the context for German leadership in foreign policy and crisis response. First, the country's prominent role in the Eurozone crisis heightened expectations of increased engagement in other areas, including in foreign policy. Second, the governing coalition changed from one composed of CDU/CSU and FDP to a so-called 'Grand Coalition' of Germany's major parties CDU/CSU and SPD. While Angela Merkel remained chancellor, foreign minister Guido Westerwelle was replaced by his once predecessor, FrankWalter Steinmeier, who initiated a year-long assessment of German foreign policy. While the Review 2014 was described as 'an educational crusade to rally the internal agents of change behind a new culture of outward and forward thinking on Germany's role in the world' (Techau 2015), it is arguably another factor which proves most 
relevant in explaining the differences between German leadership in the Libyan and Ukrainian crisis: Berlin has traditionally been much more active in Europe's Eastern neighbourhood than towards the South, and has long entertained a unique kind of Ostpolitik towards Russia (Siddi 2016) as the subsequent sections will demonstrate.

\section{SEISING RELATIVE POWER: GERMAN LEADERSHIP IN UKRAINE}

In November 2013, the Ukrainian government withdrew from negotiations of an association agreement with the EU. This decision led pro-European supporters to first protest against, and eventually overturn the incumbent government. When the latter was replaced by a pro-European administration, and the Russian government responded by annexing the Crimean Peninsula on 18 March $2014,{ }^{10}$ and by launching a proxy war in Eastern Ukraine. Stressing the illegitimate character of these actions which caused substantial harm to many Ukrainian citizens and challenged 'the post-Cold War European political and security order' (Krotz and Maher 2016, 5), EU Member States quickly agreed on a number of measures: After suspending the bilateral talks with the Russian Federation on visa matters (European Council, 6 March 2014), they cancelled a planned EU-Russia summit (European Council, 20 March 2014) and called on the Russian Federation to immediately withdraw its armed forces. Despite the freezing of assets of individuals identified as responsible for the misappropriation of Ukrainian state funds, and the explicit statement that any further steps to destabilise the situation in Ukraine would lead to 'additional and far reaching consequences for relations in a broad range of economic areas' (European Council, 20 March 2014), the conflict increased further over the next months. In response, EU governments adopted a package of additional targeted economic sanctions and, in the summer of 2014, decided on a plan which demanded Russia to take four steps to de-escalate the conflict ${ }^{11}$ (European Council meetings, 16/29 July).

While most of these measures were agreed on under the lead of the Franco-German tandem, and in cooperation with Sweden and the UK (Cross and Karolewski 2017, 4-7; Orenstein and Kelemen 2017, 94), Berlin played a particularly powerful role in the process. Already instrumental in helping to facilitate the First Minsk Protocol from 5 September 2014, German chancellor Angela Merkel became one of the key figures in negotiating the 13-point 'Minsk II' ceasefire agreement in which representatives of Ukraine, Russia, France, and Germany agreed on new measures to alleviate the ongoing war (Blome et al. 2015). This measure can be seen as an example of the doctrine of 'strategic patience' (Merkel 2015), i.e. the continued effort to engage with Russia to maintain the potential of future dialogue, even in the face of frequent failures. At the same time, this approach led to an intense domestic debate between so-called Russlandverstehern or Putin-Verharmlosern, who underlined Moscow's importance as key partner in European and global security and a major supplier of energy on the one hand, and voices warning of Moscow's aggressive attitude on the other hand (see Scherbakowa and Schlögel 2015). Even though German public opinion on the Ukraine crisis was from the very beginning significantly more divided than in the case of Libya - in December 201454 per cent of Germans were in favour of sanctions and 40 per cent against it - support for coercive measures increased as Russia's aggressions and the war in Ukraine continued. ${ }^{12}$ 
TABLE 2

TIMELINE UKRAINE - KEY DECISIONS AND ACTIONS (MARCH 2014 - MARCH 2015)

\begin{tabular}{|c|c|c|}
\hline Date & Measure & $\begin{array}{l}\text { Level of } \\
\text { activity }\end{array}$ \\
\hline $\begin{array}{r}03 / 03 / \\
2014\end{array}$ & $\begin{array}{l}\text { Extraordinary meeting of Foreign Affairs Council } \\
\text { - condemns violation of Ukrainian sovereignty and territorial integrity by } \\
\text { Russia } \\
\text { - calls on the Russian Federation to immediately withdraw its armed forces } \\
\text { to the areas of their permanent stationing } \\
\text { - states that any further steps by the Russian Federation to destabilise the } \\
\text { situation in Ukraine would lead to additional and far reaching } \\
\text { consequences for relations in a broad range of economic areas } \\
\text { - decides that those EU states that are participating in the G8 will suspend } \\
\text { their participation in activities associated with the preparations for the G8 } \\
\text { Summit in Sochi in June 'until the environment comes back where the G8 } \\
\text { is able to have meaningful discussion' }\end{array}$ & Council \\
\hline $\begin{array}{r}05 / 03 / \\
2014\end{array}$ & $\begin{array}{l}\text { Council Regulation (EU) No 208/2014 } \\
\text { - condemns Russia's actions in Ukraine and decides to start preparing } \\
\text { individual restrictive measures (assets freeze and travel bans) } \\
\text { - EU leaders also suspend bilateral talks with the Russian Federation on visa } \\
\text { matters and on the New Agreement }\end{array}$ & $\begin{array}{l}\text { European } \\
\text { Council }\end{array}$ \\
\hline $\begin{array}{l}17 / 03 / \\
2014\end{array}$ & $\begin{array}{l}\text { Council Decision 2014/145/CFSP } \\
\text { - imposes travel restrictions and asset freeze measures }\end{array}$ & $\begin{array}{l}\text { European } \\
\text { Council }\end{array}$ \\
\hline $\begin{array}{c}20-21 / 03 / \\
2014\end{array}$ & $\begin{array}{l}\text { Council Conclusions } \\
\text { - add } 12 \text { names to the list of Russian and Crimean officials subject to EU } \\
\text { travel bans and asset freezes following the annexation of Crimea and } \\
\text { Sevastopol to the Russian Federation } \\
\text { - ask the Commission and the Member States to prepare possible targeted } \\
\text { measures } \\
\text { - cancel a planned EU-Russia summit and note that member states will not } \\
\text { hold any bilateral regular summits with Russia }\end{array}$ & $\begin{array}{l}\text { European } \\
\text { Council }\end{array}$ \\
\hline $\begin{array}{r}23 / 06 / \\
2014\end{array}$ & $\begin{array}{l}\text { Council Decision 2014/386/CFSP of } 23 \text { June } \\
\text { - prohibits import into the Union of goods originating in Crimea or } \\
\text { Sevastopol } \\
\text { - sets out specific steps to be taken by Russia and the separatists for de- } \\
\text { escalation }\end{array}$ & $\begin{array}{l}\text { European } \\
\text { Council }\end{array}$ \\
\hline $\begin{array}{r}22 / 07 / \\
2014\end{array}$ & $\begin{array}{l}\text { Council Decision 2014/486/CFSP } \\
\text { - urges the Russian Federation to actively use its influence over the illegally } \\
\text { armed groups in order to achieve full, immediate, safe and secure access to } \\
\text { the site of the downing of Malaysian Airlines Flight MH17 in Donetsk } \\
\text { - urges Russia to stop the increasing flow of weapons, equipment and } \\
\text { militants across the border in order to achieve rapid and tangible results in } \\
\text { de-escalation and to withdraw its additional troops from the border area } \\
\text { - requests the Commission and the EEAS to finalise their preparatory work } \\
\text { on possible targeted measures, including on access to capital markets, } \\
\text { defence, dual-use goods, and sensitive technologies, including in the } \\
\text { energy sector }\end{array}$ & $\begin{array}{l}\text { European } \\
\text { Council }\end{array}$ \\
\hline $\begin{array}{r}\text { 31/07/ } \\
2014\end{array}$ & $\begin{array}{l}\text { Council Decision 2014/512/CFSP } \\
\text { - prohibits the direct or indirect sale, supply, transfer or export of arms and } \\
\text { related materiel of all types, including weapons and ammunition, military } \\
\text { vehicles and equipment, paramilitary equipment, and spare parts therefore, } \\
\text { to Russia by nationals of Member States } \\
\text { - decides that the Union shall encourage Third States to adopt restrictive } \\
\text { measures similar to those provided for herein. }\end{array}$ & $\begin{array}{l}\text { European } \\
\text { Council }\end{array}$ \\
\hline
\end{tabular}


TABLE 2

CONTINUED.

\begin{tabular}{|c|c|c|}
\hline Date & Measure & $\begin{array}{l}\text { Level of } \\
\text { activity }\end{array}$ \\
\hline $\begin{array}{r}\text { 19/03/ } \\
2015\end{array}$ & $\begin{array}{l}\text { Council Conclusions } \\
\text { - call on all parties to swiftly and fully implement the Minsk protocols (of } \\
\text { Sept } 2014 \text { and February 2015) and honour their commitments and } \\
\text { underlines the Russian authorities' responsibility in this regard } \\
\text { - link the duration of the previously agreed restrictive measures against the } \\
\text { Russian Federation to the complete implementation of the Minsk } \\
\text { agreements } \\
\text { - condemn the illegal annexation of Crimea and Sevastopol by the Russian } \\
\text { Federation and expresses commitment to fully implement its non- } \\
\text { recognition policy } \\
\text { - stress the need to challenge Russia's ongoing disinformation campaigns }\end{array}$ & $\begin{array}{c}\text { European } \\
\text { Council }\end{array}$ \\
\hline
\end{tabular}

Another viewpoint suggests that Berlin's policy resulted from attempts to accommodate the preferences of its European partners.

This argument appears convincing in light of the fact that during the Ukrainian crisis, the European Council became a key forum through which Berlin coordinated the EU's response to Russia's aggressions, particular in the realm of sanctions (Krotz and Maher 2016; Siddi 2016). In doing so, it sought close cooperation with larger member states, especially with France, but was also keen to promote close cooperation with smaller Member States (MacFarlane and Menon 2014; Sjursen and Rosén 2017, 25). When preparing for European Council meetings (Table 2), for instance, Germany worked closely with Poland, whose deep-seated suspicion towards unilateral German leadership had initially made it a difficult partner (Stoklosa 2017), and with the Baltic states, which felt particularly threatened by Russia (Hyndle-Hussein 2015). This provided with important voice opportunities (Orenstein and Kelemen 2017, 96) and aware of Germany's awareness of their concerns, these Member States not only embraced, but frequently welcomed German leadership on the issue (e.g. Foreign Ministry of Latvia 2014). At the same time, Berlin also sought to promote solutions that respected the interests of other countries, including Greece, Cyprus, Hungary, the Czech Republic and Bulgaria, which remained skeptical of taking a tough stance against Russia (Kuzio 2017, 111; Sjursen and Rosén 2017, 20). Thus acting as an 'honest broker' between different groups within the EU, Germany was able to assume the role of Primus Inter Pares, albeit in close cooperation with France and agreement with the British government. As such, the Ukraine crisis demonstrates how shared preferences among the Big Three on the one hand, and sufficient voice opportunities for smaller Member States on the other hand can lead to effective solutions in the European Council.

\section{CONCLUSION}

In this paper, we introduced the concept of Primus inter Pares as a way by which to describe Member States' ability to assume a position of leadership in the European 
Council. After identifying its underlying conditions - alignment of preferences among the Big Three and sufficient voice opportunities for smaller member states - we investigated Germany's role during the 2011 Libyan uprisings and the violent protests in Ukraine in 2014/15 and found considerable differences: In Libya, its power was limited by the fact that - after a period of initial agreement with Paris and London the latter promoted a military intervention that ultimately led to regime change. Unwilling to actively take part in the latter, Germany rapidly lost its ability to exercise leadership, especially as NATO's role as a key decision-making forum increased. In a similar vein, smaller member states were deprived of an their voice opportunity as the European Council's relative importance decreased. By contrast, during the Ukrainian crisis, preferences among the Big Three were largely aligned and the European Council became a vital forum for interaction between large and smaller member states. As Berlin was committed to taking seriously the concerns and requests of smaller member states, the latter not only maintained an opportunity to make their positions heard and to provide valuable input, they were also ready to embrace German leadership. On this basis, we concluded that Germany's status as Primus Inter Pares depends highly on the extent to which it is capable of cooperating with and accommodating the preferences of other member states. In addition, we found that public opinion is a particularly important constraint on the German government and that in both crises the public sentiment was irreconcilable with military action and led to an increased focus on sanctions as an alternative policy tool.

On this basis, we come to the following assessment about the future of German leadership in the area of crisis response: First, the way in which France defines its foreign policy preferences under President Emanuel Macron on the one hand, and the arrangements between the United Kingdom and Europe 'post Brexit' on the other hand, are crucial factors for Germany's ability to act as Primus Inter Pares. So far, the Macron government's initiatives to increase the EU's foreign policy capabilities have led to a cautious reaction in Berlin, and French interventions in the trade dispute with the US, EU-Russia relations, the Iran conflict, and climate change negotiations have challenged Berlin's role in shaping the EU response. At the same time, the German government has, thus far, shown only limited interest in taking more responsibility in the EU's security policy itself as evidenced by continued low levels of defence spending. While this is to be attributed to the continued scepticism among the German public regarding the use of public resources for military purposes, this approach has enabled the French government to regain its position as traditional leader in the foreign and security policies of the EU. In addition, it has provided ample room for criticism by U.S. President Donald Trump whose rhetoric and policies increasingly destabilise relations among long-standing NATO allies, EU partners and the post WWII- global order more broadly.

Meanwhile, there is still much uncertainty about how the United Kingdom intends to contribute to European foreign and security policy after 29 March 2019. Policy experts keep reminding the British government that 'leaving behind the European Union should not entail a departure from Europe', stressing that Britain 'will remain an integral and pivotal part of Europe, and particularly of European foreign and security policy' (Bridges 2018). Yet, little is known thus far about how the UK intends to cooperate with the EU and specific member states in the future. While potential diplomatic, political and military arrangements are being considered, Germany can, for the 
time-being, merely expect a necessity to reinforce its commitment to the EU's foreign and security policies after the UK's official departure.

Second, on-going discussions with Southern, Eastern and Central European Member States about asylum and migration policies suggest that Berlin has lost some of its leverage vis-à-vis smaller members, and might find it increasingly difficult to gather support for its policies. As this coincides with a weakened domestic position of Chancellor Angela Merkel following the German parliamentary elections in 2017, the question arises whether Berlin will be able to ensure that its European partners will continue to feel committed to previously shared norms and ideas. So far, Berlin's approach appears to focus on building a smaller group of supportive 'core countries' that will allow Germany to advance common interests. How this will resonate with the rest of Europe, and which institutional changes are required to make this arrangement happen both legally and in practise, remains to be seen. The form and extent of such an agreement may in and by itself be seen as evidence of Germany's ability to act as Primus Inter Pares.

\section{DISCLOSURE STATEMENT}

No potential conflict of interest was reported by the authors.

\section{ABOUT THE AUTHORS}

Wolfgang Wessels is Director of the Centre for Turkey and European Union Studies CETEUS) at the University of Cologne, where he also holds the 'Ad Personam' Jean Monnet Chair for Political Science. Since 2018 he has been a part-time professor at the School of Transnational Governance (STG) at the European University Institute (EUI), and looks back at a long academic career in numerous other prestigious institutions. He has been awarded the 'Lifetime Achievement in Contemporary European Studies' by the University Association for Contemporary European Studies (UACES) as well as the Jean Monnet Award 'European Prize for Lifelong Learning/European Studies' in Gold for his remarkable career.

Inez von Weitershausen is a postdoctoral researcher at the Massachusetts Institute of Technology and CARR visiting fellow at the London School of Economics and Political Science where she also obtained her PhD, working with Dr. Ulrich Sedelmeier. She was a visiting researcher at the Centre d'Etudes Européennes at Sciences Po Paris and at the Department of Political Science at Georgetown University. Her research focuses on the prerequisites for and dynamics of international collaboration and spans across a wide range of issue areas, including foreign and security policy, political economy and international development.

David Schäfer is a Policy Analyst at the Secretariat-General of the European Commission, unit President's and Vice-Presidents' Briefings. Previously, he was a Graduate Programme participant at the European Central Bank where he worked as a press officer in the division Global Media Relations. He holds a PhD from the London School of Economics and Political Science (LSE), an MA from the College of 
Europe and was a visiting researcher at the Hertie School of Governance and Sciences Po Paris. His research is published in the Journal of Common Market Studies.

\section{NOTES}

1. We thank the decision-makers and policy analysts in Berlin, Brussels, Paris and London who shared with us their experiences and insights regarding the dynamics in the European Council during key episodes of the Libyan and Ukrainian crisis.

2. At the European summit in The Hague in 1969 the six founding members initiated the EPC in form of loose intergovernmental policy coordination. Over time, the arrangement increasingly formalised, however, and eventually developed into the Common Foreign and Security Policy (CFSP) In the Maastricht Treaty.

3. The unanimity rule enables ach member state, independent of their relative size and capabilities, to cast a veto on foreign policy issues. While vetoes may be costly in terms of reputation and political capital, they are nonetheless issued occasionally when deemed appropriate. (Tallberg 2008).

4. In this context a distinction can be made between 'antagonistic balancing' of two or more powers in a rival relationship, and 'cooperative balancing', which despite a cooperative relationship falls short of using the constraining impact of common institutions to sustain a balanced relationship between the main powers (Link 1997).

5. Particularly influential in this regard are strategic documents such as EU's Global Strategy (EUGS, June 2016), the Review of the European Neighbourhood Policy (ENP, November 2015), the Joint Report on the Implementation of the European Neighbourhood Policy Review (17 May 2017) or the Joint Communication on 'A Strategic Approach to Resilience in the EU's External Action' (7 June 2017).

6. Official military action began after UN resolution 1973 had authorised 'all necessary means' - short of military intervention with ground forces - to protect civilians. Initially carried out by a small international coalition, led by France, the UK and the US, NATO soon took control over the No-Fly Zone as part of Operation 'Unified Protector'.

7. Malta accommodated thousands of foreigners who had been evacuated from Libya, and Italy became a member of the initial coalition force, consisting of the U.S., Britain, France, Italy and Canada.

8. On 1 April 2011 the EU presented a proposal for a humanitarian assistance mission in support of the UN (EUFOR Libya) which some may interpret as a cooperation effort. However, the mission was never deployed and MEP Anna Gomes soon argued that initiative itself was in itself a resulted from Member States; inability to reach agreement on a 'full-scale Common Security and Defence (CSDP) operation' (Gomes 2011).

9. A broad majority of Germans ( 88 per cent) supported the country's non-participation in a military mission, with only 27 percent deeming the government's decision 'wrong' in March 2011. Conversely, 70 per cent expressed their support for a trade embargo (Forsa 2011).

10. While there is little evidence to suggest that initial protests were indeed orchestrated by Russia, it appears more likely that they constituted a spontaneous reaction by the Russian speaking population in the East after the 'Maidan government' cancelled the status of Russian as an official language. Military activities by the infiltrated paramilitary and the Crimea-based Russian Black Sea fleet began as early as 27 and 28 February

11. The assets freezes were first decided in March 2014, and subsequently renewed. The measures were last extended in March 2017.

12. By February 2015, two thirds of Germans supported the sanctions (65 per cent, compared to 31 per cent against) (Infratest Dimap 2015, 7).

\section{REFERENCES}

Adler-Nissen, Rebekka, and Vincent Pouliot. 2014. "Power in Practice: Negotiating the International Intervention in Libya." European Journal of International Relations 20 (4): 889-911.

Allers, Robin Marc. 2016. "Are We Doing Enough? Change and Continuity in the German Approach to Crisis Management." German Politics 25 (4): 519-540.

Armellini, Alvise. 2011. "Diplomats Mourn 'Death' of EU Defence Policy Over Libya." Deutsche Presse-Agentur, March 24. 
Béland, Daniel, and Robert H. Cox. 2016. "Ideas as Coalition Magnets: Coalition Building, Policy Entrepreneurs, and Power Relations." Journal of European Public Policy 23 (3): 428-445.

Bickerton, C. J., D. Hodson, and U. Puetter, eds. 2015. The New Intergovernmentalism: States, Supranational Actors and European Politics in the Post-Maastricht Era. Oxford: Oxford University Press.

Blome, Nikolaus, et al. 2015. “Can Merkel's Diplomacy Save Europe?” Spiegelonline, February 14.

Bremmer, Ian, and Mark Leonard. 2012. "U.S.-German Relationship on the Rocks." The Washington Post, October 18.

Bridges, Stephen. 2018. "Global Britain: The Future of UK Diplomacy in a Post-Brexit World.” April 4, Center for Brexit Studies Blog, University of Manchester. https:// centreforbrexitstudiesblog.wordpress.com/2018/04/04/global-britain-the-futureof-uk-diplomacy-in-a-post-brexit-world/.

Brockmeier, Sarah. 2013. "Germany and the Intervention in Libya." Survival: Global Politics and Strategy 55: 63-90.

Bucher, J., L. Engel, S. Harfensteller, and H. Dijkstra. 2013. "Domestic Politics, News Media and Humanitarian Intervention: Why France and Germany Diverged over Libya." European Security 22 (4): 524-539.

Bulmer, Simon, and William Paterson. 2010. "Germany and the European Union: From "Tamed Power" to Normalized Power?" International Affairs 86 (5): 1051-1073. Clark, Ian. 2011. Hegemony in International Society. Oxford: Oxford University Press. Cross, Mai'a K. Davis, and Ireneusz Pawel Karolewski. 2017. "What Type of Power Has the EU Exercised in the Ukraine-Russia Crisis? A Framework of Analysis." JCMS: Journal of Common Market Studies 55 (1): 3-19.

Delacoura, Katerina. 2012. "The 2011 Uprisings in the Arab Middle East: Political Change and Geopolitical Implications." International Affairs 88 (1): 63-79.

Del Sarto, Raffaella A. 2016. "Normative Empire Europe: The European Union, Its Borderlands, and the 'Arab Spring'." Journal of Common Market Studies 54 (2): 215-232.

Fabbrini, S. 2013. "Intergovernmentalism and its Limits: Assessing the European Union's Answer to the Euro Crisis." Comparative Political Studies 46 (9): 1003-1029.

Fabbrini, Sergio. 2014. The European Union and the Libyan Crisis. doi:10.2139/ssrn. 2423286.

Foreign Ministry of Latvia. 2014. "Foreign Ministers of Latvia and Germany Discuss Crisis in Ukraine." March 11. http://www.mfa.gov.lv/en/news/developments-inukraine/position-of-latvia-on-the-developments-in-ukraine/13599-foreignministers-of-latvia-and-germany-discuss-crisis-in-ukraine.

Forsa. 2011. "Umfrage zum Libyen-Konflikt." cit. in Stern. https://www.stern.de/ politik/ausland/umfrage-zu-unruhen-in-libyen-deutsche-wollen-sich-nichteinmischen-3863588.html.

Gomes, Ana. 2011. “Was Eufor Libya an April Fool's Joke?” EU Observer, July 13.

Grieco, Joseph M. 1995. "The Maastricht Treaty, Economic and Monetary Union and the Neo-Realist Research Programme." Review of International Studies 21: $21-40$. 
Gross, Eva. 2007. “Germany and European Security and Defence Cooperation: The Europeanization of National Crisis Management Policies?" Security Dialogue 38 (4): 501-520.

Hyndle-Hussein. 2015. The Baltic States on the Conflict on Ukraine. Warsaw: Ośrodek Studiów Wschodnich.

Infratest Dimap. 2015. "ARD Deutschland Trend." https://www.infratest-dimap.de/ fileadmin/_migrated/content_uploads/2015.02.05_DT1502_bericht.pdf.

Katzenstein, Peter, ed. 1997. Tamed Power: Germany in Europe. Ithaca: Cornell University Press.

Keohane, Robert O., and Joseph S. Nye. 1977. Power and Interdependence. World Politics in Transition. 1st ed. Boston: Little.

Keukeleire, Stephan, and Jennifer MacNaughtan. 2008. The Foreign Policy of the European Union. Houndsmills: Palgrave Macmillan.

Koehler, Michael. 2014. "Keynote European Neighbourhood Conference of the Bertelsmann Stiftung." Berlin, November 27. https://www.bertelsmann-stiftung.de/ fileadmin/files/Projekte/88_Europa_staerken_und_verbinden/ENC_Keynote_ Koehler_27_11_2014.pdf.

Koenig, Nicole. 2012. "The EU and the Libyan Crisis - In Quest of Coherence?" The International Spectator 46 (4): 11-30.

Kouzes, J. M., and B. Z. Posner. 1991. The Leadership Challenge. San Francisco: Jossey-Bass.

Kranz, Jonas. 2011. What Role for the EU in the International System? A Constructivist Reading of the (Presidency) Conclusions of the European Council Since the Establishment of CFSP. Cologne.

Krotz, Ulrich, and Richard Maher. 2016. "Europe's Crises and the EU's 'Big Three'." West European Politics 39: 1053-1072.

Krotz, Ulrich, and Joachim Schild. 2016. Shaping Europe: France, Germany, and Embedded Bilateralism from the Elysée Treaty to Twenty-First Century Politics. Oxford: Oxford University Press.

Kundnani, Hans. 2012. "The Concept of "Normality" in German Foreign Policy Since Unification." German Politics and Society 102 (30): 38-58.

Kuzio, Taras. 2017. "Ukraine between a Constrained EU and Assertive Russia." Journal of Common Market Studies 55 (1): 103-120.

Lentner, Howard. 2005. "Hegemony and Autonomy." Political Studies 53 (4): 735-752.

Link, Hans-Werner. 1997. "Die Europäische Neuordnung Und Das Machtgleichgewicht." In Europa 2020, edited by Thomas Jäger, and Melanie Piepenschneider, 9-31. Opladen: Leske + Budrich.

MacFarlane, Neil, and Anand Menon. 2014. "The EU and Ukraine." Survival 56 (3): 95-101.

Maull, Hans W. 2000. "Germany and the Use of Force: Still a "Civilian Power”?" Survival 42 (2): 56-80.

Mearsheimer, John J. 2003. The Tragedy of Great Power Politics. New York: W.W. Norton.

Merkel, Angela. 2015. "Rede von Bundeskanzlerin Angela Merkel anlässlich der 51." Münchner Sicherheitskonferenz. https://www.bundesregierung.de/Content/DE/ Mitschrift/Pressekonferenzen/2015/02/2015-02-09-merkel-obama.html. 
Miskimmon, Alister. 2012. "German Foreign Policy and the Libya Crisis." German Politics 21 (4): 392-410.

Olender, Michael. 2012. “Germany's Euro Crisis: Preferences, Management, and Contingencies." Review of European and Russian Affairs 7 (2): 1-17.

Oppermann, Kai. 2012. "National Role Conceptions, Domestic Constraints and the New 'Normalcy' in German Foreign Policy: The Eurozone Crisis, Libya and Beyond." German Politics 21 (4): 502-519.

Oppermann, Kai, and Alexander Spencer. 2018. "The Social Construction of Mistakes: Germany's Abstention on UN Security Council Resolution 1973 on Libya.” In Political Mistakes and Policy Failures in International Relation, edited by Andreas Kruck, Kai Opperman, and Alexander Spencer, 55-77. Basingstoke: Springer International Publishing AG.

Orenstein, Mitchell A., and R. Daniel Kelemen. 2017. "Trojan Horses in EU Foreign Policy." JCMS: Journal of Common Market Studies 55 (1): 87-102.

Paterson, William. 2011. "The Reluctant Hegemon? Germany Moves Centre Stage in the European Union." JCMS: Journal of Common Market Studies 49: 57-75.

Puetter, Uwe. 2013. "The European Council - The New Centre of EU Politics." SIEPS European Policy Analysis 16: 1-16.

Puetter, Uwe. 2014. The European Council and the Council: New Intergovernmentalism and Institutional Change. Oxford: Oxford University Press.

Scherbakowa, Irina, and Karl Schlögel. 2015. Der Russland-Reflex. Einsichten in eine Beziehungskrise. Hamburg: Körber-Stiftung.

Siddi, Marco. 2016. "German Foreign Policy Towards Russia in the Aftermath of the Ukraine Crisis: A New Ostpolitik?” Europe-Asia Studies 68: 665-677.

Sjursen, Helene, and Guri Rosén. 2017. "Arguing Sanctions. On the EU's Response to the Crisis in Ukraine." JCMS: Journal of Common Market Studies 55 (1): 20-36.

Smith, Michael E. 1996. "Sending the Bundeswehr to the Balkans: The Domestic Politics of Reflexive Multilateralism." German Politics \& Society 41: 49-67.

Stoklosa, Katarzyna. 2017. "Ukraine and Russia in Crisis: The Polish View." In Neighbourhood Perceptions of the Ukraine Crisis: From the Soviet Union Into Eurasia?, edited by Gerhard Besier, and Katarzyna Stoklosa, 171-184. London/New York: Routledge.

Tallberg, Jonas. 2008. "Bargaining Power in the European Council." JCMS: Journal of Common Market Studies 46 (3): 685-708.

Techau, Jan. 2015. "The Steinmeier Review of German Foreign Policy.” Judy Dempsey's Strategic Europe, Carnegie Europe, March 19. Accessed January 11, 2018. http://carnegieeurope.eu/strategiceurope/?fa $=59422$.

Tömmel, Ingeborg. 2017. "The Standing President of the European Council: Intergovernmental or Supranational Leadership?" Journal of European Integration 39 (2): 175-189.

Vanhoonacker, Sophie. 2011. "The Institutional Framework." In International Relations and the European Union. 2nd ed., edited by C. Hill, and M. Smith, 75-100. Oxford: Oxford University Press.

Wagner, Wolfgang. 2011. "Why the EU's Common Foreign and Security Policy Will Remain Intergovernmental: A Rationalist Institutional Choice Analysis of 
European Crisis Management Policy.” Journal of European Public Policy 10 (4): 576-595.

von Weitershausen, Inez. 2015. "Foreign Engagement In Contentious Politics: Europe and the 2011 Uprisings in Libya." In Contentious Politics in the Middle East, edited by Fawaz Gerges, 155-168. London: Palgrave Macmillan.

Wessels, Wolfgang. 2016. The European Council. Houndsmills: Palgrave Macmillan. Witney, Nick, and Susi Dennison. 2015. Europe's Neighbourhood: Crisis as the New Normal. ECFR Policy Memo. http://www.ecfr.eu/publications/summary/europes_ neighbourhood_crisis_as_the_new_normal.

YouGov. 2013. "Jeder zweite Deutsche ist für einen Bundeswehreinsatz in Mali." January 18. https://yougov.de/news/2013/01/18/jeder-zweite-deutsche-ist-fureinen-bundeswehreins/. 